\title{
Analysis on Types of New Abbreviations of Russian after Collapse of the Soviet Union
}

\author{
Guojiang Qi \\ College of Foreign Languages \\ Heihe University \\ Heihe, China 164300
}

\begin{abstract}
The collapse of the Soviet Union has a history of more than twenty years. The contemporary Russian society is changing dramatically. In scientific language, political comment language and official document communication, new abbreviations are used more widely. Nowadays, abbreviation formed by shortening method has become indispensable language phenomenon in Russian. This article adopts classification method and qualitative description method to discuss new abbreviations appearing in Russian in recent twenty years from new structure type and morphological characteristics. Research of this article has certain theoretical value on enriching and supplementing lexicology of Russian and provides guidance on teaching of Russian newspaper reading and translation practice as well as has reference function on dictionary compiling.
\end{abstract}

Keywords-new abbreviations of Russian; new structure type; morphological characteristics

\section{INTRODUCTION}

After the collapse of the Soviet Union, with social development and progress of science and technology, a good deal of new abbreviations appears in modern Russian. Modern social life and modern way of thinking require that language must be time-saving and labor-saving and realize economy principle of language furthest. In speech communication, abbreviations have compression function. It is also an embodiment of economy priciple of language. (Wang Yangzheng 2008:181). The nature of word formation of compression is to form underlying word or name unit with the same meaning of word group with the help of unique way of speaking of word-building, such as lexicaization, brachytmema, nominalization and shortening, but they are often in short forms. Try to compare: оборонка-оборонная промышленность (national defense industry), ЛенинградкаЛенинградское шоссе (Leningrad Highway), наличканаличные деньги (cash). The new wave of abbreviation is one of the most distinctive characteristics in the feild of morphology in the 21 st century.

Abbreviations complete compression function in languge. Shortening is the most economic method in word-building and plays a positive role. According to the research, proper nouns in ancient Russian do not lose the way of word formation, such

Fund program: This article is one of the achievements of Research on New Abbreviations of Russian in Twenty Years after Collapse of the Soviet Union (14C043), annual project of philosophy and social science research plan of Heilongjiang province in 2014, gets " subsidy from support plan of young top-notch personnel of scientific research in Heihe University". as Святополк, Святослав, Новгород. However, the most prosperous period of abbreviation is in 20th century. Therefore, all kinds of evaluations on abbreviations from many experts and language carriers appear. Abbreviations are widely described in literature of language and popularization of science.

Many lexical units that use the form of word group to express new things and new phenomenon in contemporary Russian society are fixed in way of abbreviations, and rapidly popularized in Russian newspapers, scientific and technical literature and words used in daily life. The structure type and morphological characteristics of new abbreviations are enriched gradually. Most new abbreviations coexist with original words. They are corresponding and have the same meaning in expression. But they are different in range of application and style: original words are serious and abbreviations are concise (Wang Xiaojuan 2009:73).

\section{ACRONYM}

It refers to new abbreviations used in Russian text and formed by first letter in English. This type of abbreviation is formed by phoneme at the beginning of words. Today, it is still the most productive formation of abbreviations in Russian. It involves all the social fields and covers a wide range. Such as: SC - The Shanghai Cooperation Organisation, SARS Severe Acute Respiratory Syndrome, MOOC - Massive Open Online Course.

Linguistic data shows that these abbreviations have corresponding acronyms in Russian. Under the same context, they can be used as synonyms, such as: LCD (ЖКД) - Liquid Crystal Display

\section{Жидкокристаллический Дисплей}

Единственным недостатком LCD телевизоров является угол просмотра. Современные ЖКД телевизоры имеют угол просмотра 170 градусов. Средний срок службы таких телевизоров составляет более 30 лет. (Visual angle is the only drawback of LCD TV. The visual angle of modern LCD TV can reach up to 170 degrees. The mean life of this kind of TV can reach thirty years.)

This kind of abbreviations does not include Russian alphabet. They belong to nouns with invariant case. Its grammatical gender are the same with that of Russian words 
corresponding to main word in full name in English, such as: B России был выявлен только один случай заболевания TOPC, заболевший Денис Сойников был помещён в больницу Благовещенска 8 мая и выписан 11 июня 2003 года. (Russia finds there is only one patient, Genese Sony Cove, who suffers from serious acute respiratory syndrome, is hospitalized in Payakumbuh in May 8th, 2003 and leaves hospital in June 11th of the same year.) TOPC belongs to masculine nouns. Кроме того, обычно на встречах G20 присутствуют представители Международного Валютного Фонда и Всемирного Банка. (Besides, usually, IMF Chief and the president of the World Bank also attend summit of G20). G20 (Группа двадцати) belongs to feminine noun.

\section{APPOSITIVE ABBREVIATION IN ENGLISH AND RUSSIAN}

Appositive is a special attribute and represents another name of things in nouns and embodies in group with double components and coordinate relation. As subordinate compositions of these groups, appositives not only refer to things expressed by main words but also explain main words on meaning. They are abbreviations formed by acronym in English and a complete Russian noun with en dash between them. Same as Chinese, with advance of globalization, abbreviations in Russian also appears many foreign abbreviations, which are directly used frequently and become more similar to Russian. It shows that people are not satisfied with old patterns in using language but pursue creating something new and original to make languages used in nowadays rich in changes. Such as.

\section{SIM-карта（Subscriber Identification Module）}

This card is provided for GSM network clients to identify identity and makes voice messaged of customer calls become enciphered. The computer chip of it stores customer information of digital mobile phone.

\section{POS-системы (Pointofsales)}

This is information management system of point of sale, with cash and trade credit teller functions, provides data services and management functions for trading of goods and media and carries out non-cash settlement.

\section{IT-отрасль（Information Technology）}

IT industry mainly involves sensor technology, communication technology and computer technology.

Grammatical gender of this kind of abbreviations is the same as that of Russian nouns contained, such as: Основная функция SIM-карты-хранение идентификационной информации об аккаунте, что позволяет абоненту легко и быстро менять сотовые аппараты, не меняя при этом свой аккаунт, а просто переставив свою SIM-карту в другой телефон. (Main functions of SIM cards are to store identification information of account number and let users easily and quickly replace mobile phones, and directly move SIM card of their own to other mobile phones. At this time, they cannot replace account number of their own.) SIM-карта belongs to feminine noun of the second declension method. Девчата (TV-шоу) - еженедельное юмористическое шоу, выходящее в эфир по пятницам на телеканале "Россия-1". (Girls TV show is weekly humorous TV show and is played in 1 channel of Russia every Friday). TV-шоy belongs to indeclinable neuter.

\section{HOMONYM ABBREVIATIONS}

The relation of homonym refers to the relation that the pronunciaton and written form are the same but the meanings are different. (Zhang Jiahua, 2006:61). Words with the relation of homonym are called homonym. The initial letters of constrictive words form a new word well-know by us. New abbreviations of Russian also include this type. For example.

Abbreviation: TOPC [торс]-Тяжёлый острый респираторный синдром (Severe Acute Respiratory Syndrome)

\section{Word: Topc (body)}

More vivid acronym in English, such as:

Abbreviation: BRICS[briks]-Brazil, Russia , India , China, South Africa

Word: brick [brik]

BRIC includes Brazil, Russia, India and China. In 2011, South Africa joined in. So it is changed into "BRICS". The pronunciation of BRICS formed by initial letters of these countries is the same as English word bricks (plural form of brick).

This type of abbreviation is often used together with common nouns that represent corresponding practical significance, such as: Российская демократическая партия “Яблоко"- политическая партия современной России. В 1993-2003 партия была представлена фракцией в Государственной думе России. ("Yabloko" Democratic Party of Russia is the party in contemporary Russia. During 1993 and 2003, it was representative party in Russian State Duma.) The name of the party of "Yabloko" is formed by the initial letters in the surnames of founders: Yavlinskiy (Явлинский), Vladimir Boldyrev (Болдырев) and Lukin (Лукин). Because it is the same as the first three letters of apple (яблоко) in Russian, it is commonly known as

"Яблоко". The logo of this group is "Apple". At this time, the form of common nouns changes. Abbreviations do not have declension. There is no need to consider its grammatical gender in using.

Of course, homonym abbreviations can be used independently without common nouns. At this time, abbreviations do not have declension. В связи с введением ЮАР в состав БРИК, в Рунете появилась альтернативная БРИКС русская аббревиатура БРЮКИ. (In view of the fact that South Africa joins in the BRIC, another abbreviation in RussiaБРЮКИ of the BRICS appears on the internet of Russia). BRICS (БРЮКИ) is formed by the initial letters of five countries, namely Brazil (Бразилия), Russia (Россия), South Africa (ЮАР), China (Китай) and India (Индия). It is same as Russian word "брюки (trousers)", which is often appeared on internet. Homonym relation between lexical units widely exists in natural language. It is a drawback for accurate 
communication. However, different meanings caused by this relation can be eliminated with the help of context.

\section{ABBREVIATIONS OF COGNATE RECURRENCES IN ENGLISH AND RUSSIAN}

It refers to the abbreviation formed by an acronym and a word contained in original word group. New abbreviations of this kind are rare. For example.

НТТР-протокол (HTTP-hypertext transfer protocol) hypertext transfer protocol

It is a kind of data transfer protocol and stipulates rules of intercommunication between browser and WWW server. Disc

DVD-диск (DVD-Digital Versatile Disc) digital versatile

It is optical disc storage, the successor product of $\mathrm{CD} / \mathrm{LD} / \mathrm{VCD}$ and can play films of standard definition and high quality music.

Grammatical gender of this type of abbreviations is completely the same as that of Russian nouns contained. The change of word form only appears in Russian words. For example: Также SIM-карта может хранить дополнительную информацию, например телефонную книжку абонента, списки входящих/исходящих телефонных номеров, текст SMS-сообщений. (SIM card can also store additional information, such as telephone directory of users, list of phone number and SMS text.) SMSсообщений belongs to neuter and the plural form of the second case.

Первые DVD-диски появились в ноябре 1996 года в Японии. В марте 1997 года они появились в США и СНГ. (The first batch of DVD optical disc appeared in Japan in November 1996. In March 1997, they appeared in America and Commonwealth of Independent States.) DVD-диски belongs to masculine nouns, plural form of the first case.

\section{ABBREVIATIONS OF SYMBOL TYPE}

In Russian, abbreviations of symbol type mainly rely on signs such as ".", “-"and"“" to achieve the purpose of shortening. The characteristic is that it is only written abbreviation of pair words or word group. It conforms to pronunciation of the original word or original word group. The quantity of this kind of acronym is small.

\section{For example: куда.py (Qunar.com)}

This abbreviation is formed by "куда", marked symbol "." and abbreviation "py" together. "Qunar.com" is the network of a travel agency with development prospect. This network is one of the biggest networks in Russia. It has more than 100 offices in 40 cities of Russia. The company was established in 2001. In 2006, the tourism industry of the company completes almost the biggest deal, more exactly, tourism trade. $25 \%$ of stock of the company is approximately about $13,500,000$ U.S. dollars.
For example: $\quad$ ГАС-выборы-Государственная автоматизированная система по учёту голосов избирателей ( National automated ballot counting system)

The abbreviation is formed by abbreviation " $Г А C "$, marked symbol "_" and “выборы"together. The resolution on establishing national automated ballot counting system was adopted by Order of President of Russian Federation No. 1723, On Formulation and Establishment of State Automatic System of Election in Russian Federation, in August 23rd, 1994.

For example: a/я-абонементный ящик (ticket box of reservation)

The abbreviation is formed by abbreviation"a", marked symbol"/"and abbreviation" 9 "together. Ticket box of reservation refers to dedicated closed grid box, to collect and temporarily preserve postal matters (letter and postcard) and small printing materials. It exists in postal enterprise and has corresponding number or name.

Because of popularization of advertising industry, to pursue conciseness and save money, the abbreviation of symbol type is widely used in advertisement (especially private advertisement). For example.

Холодильник “Морозко" н. или б/у в х. с. The typical private advertisement shall be interpreted as Куплю холодильник “"Морозко ” новый или бывший в употреблении в хорошем состоянии. (I will buy a set of new or second-hand refrigerator of "Santa Claus"brand in good condition.)

Grammatical gender of this kind of abbreviation is completely the same as that of Russian nouns contained. Such as: Сеть магазинов “ручка.pу” была создана в 1994 году и в настоящий момент насчитывает 14 магазинов, расположенных в лучших торговых центрах города Москвы. В наших магазинах представлены коллекции эксклюзивных пишущих принадлежностей самых известных фирм производителей со всего мира. В 2009 году журнал Newsweek UK признал компанию "ручка.ру” №1 в мире по количеству проданных ручек. (“ручка.ру” online store was established in 1994. Nowadays, there are fourteen stores in total distributed in the best trade center of Moscow. The store provides the exclusive stationery collectibles of the most famous production company in the world. In 2009, British magazine News Week called "ручка.py" as the company that sells the most quantity of fountain pen.) ручка.py does not have changes of word form in quotation mark ““.. The meaning of py is русский (Интернет), belonging to adjective of masculine gender.

For example: В акватории Восточно-Китайского моря во вторник начнутся третьи по счету российско-китайские военные учения “Морское взаимодействие-2014”.

В торжественной церемонии их открытия в Шанхае примут участие президент РФ Владимир Путин, прибывающий в Китай с официальным визитом, и председатель КНР Си Цзиньпин, передаёт ИТАР-ТАСС. (According to Itar Tass News Agency: The third Sino-Russian military exercise with code name of "joint-2014" will be held in water area of the East China Sea in Tuesday. President 
of the Russian Federation, Vladimir Putin for official visit in China and Chairman of China Xi Jinping will attend the grand opening ceremony of the military exercise in Shanghai.) The central word of ИТАР-ТАСС (Информационное телеграфное агентство России-Телеграфное агентство Советского Союза) is агентство, belonging to neuter. According to the research, although the Soviet Union has gone with the wind, andСоветский Союз becomes word in history, its abbreviation is still retained in name of the biggest news agency ИТАР-ТАСС in Russia. (Cheng Jiajun, 2001:89).

For example: Согласно Федеральному закону Российской Федерации "О почтовой связи" “почтовый $\mathrm{a} /$ - - специальный запирающийся ящик, предназначенный для получения адресатами почтовых отправлений“. (According to Law of Post of Russian Federation, the ticket box of reservation refers to dedicated closed grid box set up for recipients to accept the mails.)

Because language is "the mirror of social life and 'barometer' of social development and change", emergence of many new technologies, new products and other new formations greatly enriches language. The quantity of abbreviations also increases accordingly and unceasingly. The structure type and morphological characteristics of new abbreviations are diversified gradually. The research result of this article can be used in vocabulary teaching of Russian as a foreign language. The concrete results of the research can be used for the process of improvement to correctly use written and spoken Russian of new abbreviations, as well as provide reference basis and methods and ideas for research on other language phenomena.

\section{REFERENCES}

[1] Cheng Jiajun. Modern Russian and Modern Russian Culture [M], Shanghai: Shanghai Foreign Language Education Press, 2001.

[2] Wang Yangzheng. Social Changes and Changes of Russian Language [M], Harbin: Heilongjiang People's Publishing House, 2008.

[3] Wang Xiaojuan. Economy Principle of Language-Comparative Study on Spoken Russian and Spoken Chinese [M], Beijing: China International Broadcasting Publishing House, 2009.

[4] Zhang Jiahua. Generall Theory of Russian in New Era (Volume One), Beijing: Commercial Press, 2006. 